\title{
IMPLEMENTATION OF THE FREE EDUCATION POLICY IN PRIMARY SCHOOLS IN KAFUE DISTRICT: IS IT A COMPROMISE ON QUALITY OF EDUCATION IN ZAMBIA?
}

\author{
Christine Mwanza ${ }^{1}$, \\ Darious Silukuni ${ }^{2}$ \\ ${ }^{1}$ The University of Zambia, \\ School of Education, \\ Zambia \\ 2Ministry of General Education, \\ Zambia
}

\begin{abstract}
:
In this study, researchers investigated the implementation of Free Primary Education Policy in selected primary schools of Kafue district of Zambia. The study's objective was to determine the possible conflicts that had arose between learners' access to education and supply of quality education. As a descriptive survey, the study population consisted of one hundred and twenty (120) teachers, twenty-four (24) head teachers one (2) Ministry of General Education (MoGE) officials. The teachers responded to a questionnaire while the head teachers and MoGE officials were interviewed using structured interview schedules. An observation checklist was used to record the schools' enrolments, equipment and facilities that were available. Data was analyzed thematically as themes and sub themes emerged from the data. Finding showed that there were high enrolments in Kafue primary schools, an indication that many learners had free access to education but this led to a number of challenges such as: inadequate educational supplies, low staffing levels, inadequate classrooms and desks. Teachers were being overworked and were unable to attend to individual needs of pupils. They also could not manage to give adequate homework and remedial work due to large classes. Consequently, the Zambian government seems to have failed to meet the needs of primary schools in Kafue due to the surge in enrolments. Scholars in this study recommended that the Ministry of General Education should evaluate the practicality and sustainably of the Free Primary Education in all primary schools in Kafue district. Furthermore, additional funds should be allocated for schools to enable them buy teaching and learning materials.
\end{abstract}

Keywords: curriculum implementation, free primary education policy, quality education 


\section{Introduction}

At the 1990 World Conference on Education for All in Jomtien, delegates from 155 countries including Zambia agreed to make primary education accessible to all children and to massively reduce illiteracy before the end of the decade (Kelly 1991). The World Declaration on Education for All at this conference, thirty years ago, urged countries to intensify their efforts to meet the basic learning needs of all and to have realized universal access to primary education by 2000. Kelly (1991), further claimed that in Zambia the National Conference on Education for All was held in March 1991 as a follow up to the Jomtien conference. The National Conference set targets on how to achieve universal primary education before 2015. Children everywhere, boys and girls alike, were to be given the opportunity to complete a full course of primary school (MoE, 1996). The National Conference on Education For All resulted in the formulation of educational policy documents such as Focus on Learning in 1992 and Educating our Future in 1996 which stressed the importance of giving special focus on: decentralization of the educational system, accountability and cost sharing (Kelly, 1999).

To reaffirm its commitment to achieving these goals, the Zambian government through the Ministry of Education, on 15th March 2002, announced the "Free Education Policy", which applied to grades 1 to 7 of the formal school system for the primary school level. In terms of justification, one section of the policy circular stated that: "The announcements were seen in the context of unprecedented decline in enrolment rates and increasing dropout rates even after those years of the Basic Education Sub-Sector Investment Programme (BESSIP) whose objectives were to increase enrolment and improve learning achievement" (MoE 2002). UNESCO (2003) stated that with the free education policy, the Ministry of Education had committed itself to supporting all the schools in the country through grants of about $\$ 500-\$ 600$ per term, through funding of BESSIP. The funds were meant to support school requisites such as books, chalk, paper, pencils and other teaching and learning inputs. This project was done almost twenty years ago now. One wonders what the situation is like today given that the Ministry of General Education in Zambia still continues with the policy of free primary education despite funding to the education sector having being declining each year that passes since 2015 (Mulenga and Kabombwe, 2019b). Picking on a district, which is just fifty kilometers from the country's administrative capital city researchers in this study delimited their research to Kafue district in Lusaka province.

Despite the increased to access and enrolment to education at primary levels being high, there seem to be not much information on the prevailing circumstances between learners' access to education and supply of quality education in primary schools of districts such as Kafue. A research such as this one is vital because, primary schools in Zambia continue to experience challenges that hinder the provision of quality education which lead to continued drop outs at grade seven as indicated in the 2016, 2071 and 2018 educational statistical bulletins. Additionally, national assessment surveys such as EGRA, EGMA, PISA D, SAQMEC and others continue to reveal low literacy and 
numeracy levels in the country, Kafue included having been negatively affected. This actually resonant with what Mulenga and Lubasi (2019:64) explained that 'curriculum implementation is a very crucial stage of any curriculum development process. The problems that may arise during implementation can cause disparities in the intended curriculum, implemented curriculum and achieved curriculum'. It was therefore cardinal to follow up this policy in relation to how the curriculum was being implemented.

\section{Theoretical Framework}

According to Maslow (1968), the hierarchy theory of needs had made a major contribution to teaching and classroom management in schools. Rather than reducing behaviour to a response in the environment, Maslow adopted a holistic approach to education and learning. He looked at the entire physical, emotional, social, and intellectual abilities of an individual and how they impact on learning (Maslow 1970).

He continued to state that his hierarchy theory of needs was aimed at describing human behaviour and motivation, and why it was difficult for those who did not get their basic needs to reach their dreams or dream at all. In his theory Maslow stated that when someone was struggling to fight off the distraction of getting basic needs, it was hard to be motivated to do anything else, even if it was the solution to their problem (Maslow 1968).

Maslow (1970) argued that a hierarchy of human needs was based on two groupings. Thus, deficiency needs and growth of needs. Within the deficiency needs, each lower need was to be met before moving to the next higher level. Once each of these needs had been satisfied, the learners were motivated to move to the next level. In other words, a person was supposed to have the basic needs met before he or she was free to progress through subsequent stages of need to reach self-actualization, a stage in which they were seen to be creative and self-sufficient. Maslow (1970) continued to argue that when basic needs are not met in class, learners failed to focus on learning leading to high dropouts.

The link between Maslow's Hierarchy theory of need and this study is that Maslow was more concerned about learners meeting their basic needs first in order for them to perform well in a classroom while the Free Primary Education policy is concerned about creating an enabling environment for every learner to have access to education despite their economic status and cultural background. Therefore, both Maslow's Hierarchy theory of need and the Free Primary Education policy are concerned about the education needs of the learners. These needs create a conducive environment for learners to perform well. In other words, poor learning environments are likely to have a negative impact on the learners' progress from one learning level to another and may lead to high drop outs and low literacy levels. 


\section{Brief Literature Review}

\subsection{International Conversions on Free Education Policy}

The European Convention on Human Rights had been understood to establish an entitlement to education. The right to education includes the right to free, compulsory primary education for all. The right to education also includes a responsibility to provide basic education for individuals who have not completed primary education. Beiter (2005) claimed that in addition to access to education provisions, the right to education also encompasses obligations to eliminate discrimination at all levels of the education system, to set minimum standards and to improve quality.

Siaciwena and Lubinda, (2008) argued that charging of school fees to learners have had a negative impact on many governments around the world. It was because of such negative impacts that Non-Governmental Organizations, had begun to champion user fee elimination for basic public services which included primary education. This was rooted in the November 1948 declaration of human rights where members of the United Nations declared the right to education for all people. Worldwide, the aspect of investment in primary education has been a key element in the development process. Knight and Sabot (1990), established that primary education improved the earnings of its graduates by 19 percent in Kenya and 13 percent in Tanzania. In such a process, there is always apparent social benefit that accrues from primary schooling, which includes reduced fertility, better health care and decreased child mortality. Due to social benefits of primary education, most countries worldwide have prioritized primary education. In the United States of America (USA) for instance, elementary schooling is free and compulsory to all children. Kelly (1991) reported that in India, the central government provided 80 percent of financing to Free Primary Education, while the local states implement and provide the rest of financing.

\subsubsection{Impact of User Fees on School Enrolment}

A wide body of evidence shows that the costs of schooling inhibit school enrolment. Parents in Indonesia, China, the Solomon Islands and many African countries like Kenya, Malawi, Zambia, Uganda and Tanzania cite user fees as a major obstacle to enrolling their children in school (Saroso, 2005). In 2001, parents and teachers in Tanzania observed that non-payment of fees was the principal reason why children did not attend school (Oxfam, 2001). In Zambia it is estimated that at least 45 percent of children who drop out of school do so because they cannot pay school fees (Tembo and Ndhlovu 2005).

Additionally, there are few empirical studies on the ways in which user fees impact enrolment. In Kenya, absenteeism and drop-out rates have been shown to rise and fall in line with user fees (Mukudi, 2004). Mukudi further reported that user fees accounted for 31 percent of the time that children did not attend school. Before user fees were eliminated, children who did not pay school fees were often locked out of school or sent home. An econometric analysis of the impacts of Uganda's Universal Primary Education (UPE) Policy showed that parental income became a less important 
determinant of enrollment after school fees were eliminated (Deininger, 2003). In 1992, the proportion of children in Uganda who were not enrolled in school due to costs related to schooling was estimated at 71 percent. After direct fees were eliminated this figure dropped to 37 percent.

Additionally, the global survey results on the impediments of user fees have helped policy makers to understand their effect (user fees) of limiting education opportunities for the poor. The survey conducted by the World Bank and published in 2004, showed that user fees were burdensome to poor families in countries experiencing slow economic growth and inflation (Kattan, 2006). Prior to the above survey, the study under the United Nations Project "Task Force on Education and Gender Equality" revealed that the support by donors to ensure quality basic education was not adequate in Africa. According to Kaulule (2006), there were more than 100 million children out of school in Africa that time. Therefore, the study made recommendations of alleviating the problem, which included interventions and actions such as removing school fees.

In support of this move, the School Fee Abolition Initiative was launched by UNICEF and the World Bank in 2005 which grew in partnership between government representatives, agency partners, research and academic institutions (Nielsen, 2009). This was to re-emphasize the Jomtien 1990, Dakar 2000 and other educational conferences which insisted on Education for All by 2015. The focus was exclusively on the elimination of basic education fees because it was at that level that the Education for All movement had declared that education was to be free (World Bank and UNICEF, 2009). The basic or primary level was also the only level at which most governments' constitutionally pledged to provide state-sponsored schooling.

\subsubsection{Free Primary/Basic Education in Sub-Saharan Africa}

From the early 2000, several countries in Sub-Saharan Africa had abolished Primary School tuition fees as part of renewed attempts to resurrect their education systems which had been in decline, and even suffering reduced enrollments after the initial growth following independence (Verspoor, 2006). Whereas from the eighties and early to midnineties, cost-sharing had been a policy promoted by international financial institutions such as the World Bank, direct (and indirect) costs to parents of their children's education became obstacles to their attendance and continued enrollment. The inability of parents to afford such costs fell on girls disproportionately, typically being the first to be pulled out or allowed to drop out of school (UNESCO, 2003).

Although, Free Primary Education was introduced with the good intentions of increasing access to education, a number of African countries had problems regarding financing of the programme. These include Malawi, Uganda and Zambia due to their declining economies. The Free Primary Education Policy had enhanced access to education provision leading to an increase in enrollment of pupils while risking bringing about decline in the quality of education. While it is good that enrollment increased in schools. For example, the enrollment in Zambia increased from 2.7 million to 7.5 million that had defied the reality because teachers were unable to cope with the big numbers. It 
had been argued that before the introduction of Free Primary Education, it was easier to have individual pupil attention but that was not the case then (Duncan, Macmillan and Simutanyi, 2003). Additionally, teaching and learning resources were inadequate due to insufficient funding. For example, in the Delta State of Nigeria, although the intent in the policy statement was that education was to be free, the financial burden of government later forced parents to get involved in the funding of basic level of education. Since most of the parents were poor, their children remained poorly equipped to learn. With all these experiences in other African countries this study was aimed to finding out the extent to which free primary education in Kafue district in Zambia was being managed in relation to the provision of quality education.

\section{Research Method}

This study employed a descriptive survey design and focused on the challenges of implementing the Free Education Policy in primary schools in Kafue district in Zambia with emphasis on the link between access to education and the provision of quality education. The reason for using a descriptive survey was to allow for a detailed description of the state of affairs on the stated phenomenon in the district. The description was based on the views collected from the District Education Board Secretary (DEBS), District Education Standards Officers, Head teachers and teachers. The study was conducted in ten (10) primary schools from both rural and urban setting of the district.

The researchers collected data using three research instruments namely; questionnaires, interview guides and an observation check list. The three instruments were used to collect data to help answer questions that were raised. They were also used to collect background information about the respondents. An observation check list was used so as to supplement information that was given in interviews and questionnaires.

Data was then analyzed thematically and also using descriptive statistics. For instance, data which were collected from closed-ended items in the questionnaire were analyzed by the use of descriptive statistics in form of percentages and frequencies. The Statistical Package for Social Sciences (SPSS) was used to enhance the analysis. The responses were put into categories according to the emerging themes. This allowed objective and critical interpretation, so as to make decisions that were valid for conclusions and recommendations.

\section{Findings and Discussion}

The research question of this study was aimed at determining the relationship that existed between free access to education and provision of quality education in Kafue district. In order to get the correct information bases on the given question, the researchers decided to divide the question into three categories as, Pupil-Teacher Ratio, Pupil-Desk Ratio and Pupil-Book Ratio. 


\subsection{Pupil-Teacher Ratio}

Pupil-Teacher ratio is an important phenomenon in the provision of quality education especially at primary level. In order to determine this, the researchers asked the teachers to state the average number of pupils in their classes. The information indicated that 11 teachers representing (9.2\%), handled classes of sizes ranging from 1 to 40.45 teachers representing $37.5 \%$ indicated that they taught classes of sizes ranging from 41 to 60,42 teachers representing $35.0 \%$, handled classes of sizes ranging from 61 to 80 and 22 teachers representing $18.3 \%$, handled classes of sizes ranging from 81 to 100 . As indicated by the statistics, the majority of the classes were overcrowded. These details are shown in Table 1.

Table 1: Frequency and percentage distribution of teacher's responses on Pupil-Teacher Ratio

\begin{tabular}{lcc}
\hline Ratio & $f$ & $\%$ \\
\hline $1: 40$ & 11 & 9.2 \\
$41: 60$ & 45 & 37.5 \\
$61: 80$ & 42 & 35.0 \\
$81: 100$ & 22 & 18.0 \\
\hline Total & 120 & 100 \\
\hline
\end{tabular}

The majority of the schools had a Pupil-Teacher Ratio exceeding the government Pupil Teacher Ratio standards of between 35:1 and 40:1 per class. However, not only did the high numbers of pupils led to high Pupil-Teacher Ratio but also led to overcrowding of classes. Out of the 120 teachers that took part in the study, 109 (90.8\%) of the respondents indicated that their classes were overcrowded. This revealed that the majority of the schools had overcrowded classes; which further exacerbated other challenges such as inadequate desks and high pupil-book ratios.

When asked whether the classrooms were over enrolled in their schools, one male head teacher from an urban school said that;

"Yes, indeed, you would be surprised that sometimes one teacher is teaching as many as 95 children, who are congested in one small classroom. There is not even a single space to move from one child to another. That makes it extremely difficult for the teacher to give each learner enough attention. In summer, some children collapse and faint because of heat and poor ventilation in that small classroom".

One teacher also mentioned that;

"We have even become used to dealing with so many pupils in class. The class that I teacher for instance has 71 pupils and I tell you it is very difficult to control the class and also to mark their work".

The other aspect that researchers followed up was the pupil-desk ratio. 


\subsection{Pupil-Desk Ratio}

When the teachers were asked on the pupils-desk ratios in their classes, $6(9.6 \%)$ of teachers taught classes with the ratio of 1 to 2 learners per desk. 27 (22.5\%) of teachers handled classes with the ratio of 3 to 4 learners per desk, $50(41.6 \%)$ of teachers taught classes of the ratio of 5 to 6 learners per desks, $32(26.7 \%)$ of teachers taught classes with the ratio of 7 to 8 per desk while $5(4.3 \%)$ teachers indicated that they taught the classes of the ratio of 9 to 10 learners per desk in each classes. These details are shown in Table 2.

Table 2: Frequency and percentage distributions of pupils according to Pupil-Desk Ratio

\begin{tabular}{lcc}
\hline Ratio & $f$ & \% \\
\hline $1: 2$ & 6 & 5 \\
$3: 4$ & 27 & 22.5 \\
$5: 6$ & 50 & 41.6 \\
$7: 8$ & 32 & 26.6 \\
$9: 10$ & 5 & 4.3 \\
\hline Total & 120 & 100 \\
\hline
\end{tabular}

In an interview with the District Education Board Secretary (DEBS), he also confirmed that;

"The Pupil-Desk Ratio is extremely poor in most primary schools more especially in rural areas. It is not surprising to find learners sited on the floor because in some schools the situation is really bad. Combined with the primary schools limited financial resources and the large numbers of pupils in classes in most schools, it is really difficult for primary schools to purchase enough desks for every learner to learn comfortably".

If learners were to sit comfortably and be able to do school work in class each desk would only need two pupils.

\subsection{Pupil-Book Ratios (PBR)}

One of the key teaching and learning resources in most Zambian schools are textbooks as Musilekwa and Mulenga (2019:99) confirmed that 'textbooks play an important role in education because of their close relation to the classroom teaching and learning process'. When asked whether schools in Kafue District were well equipped with adequate teaching and learning materials and met the government standard Pupil-Book Ratio, the DEBS informed the researchers that all the government primary schools still had a greater challenge of the Pupil-Book Ratio. The DEBS explained that;

"The Pupil-Book Ratio is one of the major challenges all the primary schools are facing in Kafue district though the government is trying all its best to address it. This year the situation has slightly improved because as a district we were able to receive at least many 
books of Literacy for grades 1 to 5 but there is still a greater task by the government to reduce the Pupil-Book Ratio to reach the government standard of 1 book per learner".

Furthermore, teachers were asked to indicate the Pupil-Book Ratio in their classrooms. It was revealed that $11(0.9 \%)$ of the teachers taught in classes with a pupilbook ratio of $1: 2,18(15.4 \%)$ of the teachers handled classes with $1: 3$ of PBR, and $20(17.1 \%)$ of the teachers handled classes with 1:4 of PBR. 22 (18.8\%) of the teachers handled classes with 1:5 of the PBR, 29 (24.8\%) of the teachers handled 1:10 of the PBR, while $27(23.1 \%)$ of the teachers handled classes with 1:15 of PBR. These details are shown in Table 3.

Table 3: Frequency and percentage distributions of teacher's responses about the Pupil-Book Ratio in their classrooms

\begin{tabular}{lcc}
\hline Ratio & $f$ & \% \\
\hline $1: 2$ & 11 & 0.9 \\
$1: 3$ & 28 & 15.4 \\
$1: 4$ & 35 & 17.1 \\
$1: 5$ & 51 & 18.8 \\
$1: 10$ & 29 & 24.8 \\
$1: 15$ & 27 & 23.1 \\
\hline Total & 120 & 100 \\
\hline
\end{tabular}

If basic teaching and learning resources such as text books are not adequate then one wonders how the competency based curriculum that was adopted in the Zambian primary and secondary school curriculum will be effectively implemented. Moreover, Mulenga and Kabombwe (2019a:128) clearly explained that "learning in a competency-based curriculum should be visible in the learner and not simply theorized ...."

\subsection{Other challenges hindering the implementation of FPE Policy in primary schools}

After a physical observation of the school environments, equipment and facilities, the researchers asked the teachers to identify some of the hitches they experienced because of the free access to education. The responses revealed that free access to education had brought a number of problems in most primary schools of Kafue district. These problems included absenteeism, large classes, pupils continued to proceed to the following grades while they were still unable to read and write, inadequate teaching staff, high number of pupils who fail during Grade 7exams, imbalanced education demand and supply of quality, enrolment of over-aged pupils, high dropout rates, and poor water and sanitation. These details are shown in Table 4. 
Table 4: Frequency and percentage distributions of challenges teachers and administrators faced due to free access to education

\begin{tabular}{|l|cc|cc|}
\cline { 2 - 5 } \multicolumn{1}{c|}{} & \multicolumn{2}{c|}{ Teachers } & \multicolumn{2}{c|}{ Administrators } \\
\hline Challenge & $f$ & $\%$ & $f$ & $\%$ \\
\hline Inadequate Fund & 24 & 100 & 24 & 100 \\
Delays in the grant & 24 & 100 & 24 & 100 \\
Over Enrolment & 20 & 83.3 & 20 & 83.3 \\
Inadequate Toilets & 20 & 83.3 & - & - \\
Inadequate Teacher's Accommodation & 20 & 83.3 & 20 & 83.3 \\
Inadequate Staffing & 20 & 83.3 & 20 & 83.3 \\
Limited Classroom Space & 18 & 75.0 & 18 & 75 \\
Irregular Provision of FPE materials & 18 & 75.0 & 18 & 75 \\
Inadequate Water Points & 18 & 75.0 & - & - \\
Inadequate Stocks of Educational Materials & - & - & 18 & 75 \\
\hline
\end{tabular}

\subsubsection{Impact of Challenges on the provision of Quality Education}

When asked what the teachers thought would be the impact of the above-mentioned challenges on the quality delivery of education, the results showed negative impact on the quality of education provision in Kafue district. The reason being that there was poor quality education provision which resulted in low literacy levels because teachers were unable to teach effectively which led to poor performance of the learners in schools. Other challenges included; high pupil absenteeism, reduced learning time because teachers attended to several sessions, lack of teacher motivation, no remedial work, teachers were overworked and could not give enough homework to assess their classes. These details are shown in Figure 1.

Figure 1: Frequency and percentage distribution of teachers' responses on the impact of free education on quality education provision

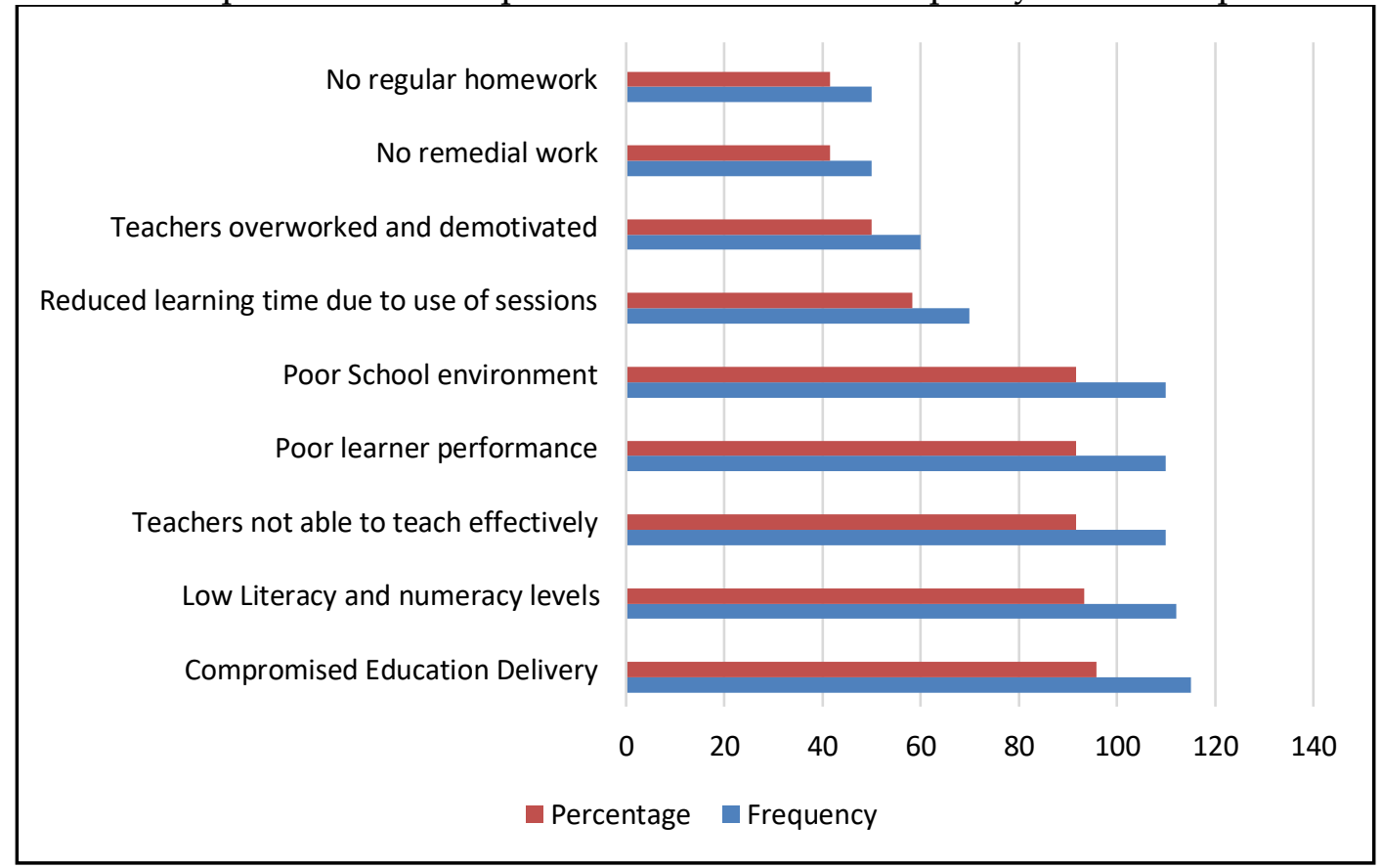




\subsubsection{Strategies Employed by Schools to Cope with the Challenges}

Head teachers were asked to mention some of the strategies they had put in place to mitigate the above-mentioned challenges. Most of the head teachers found it difficult to explain clearly on some of the strategies their schools had put in place because they still bordered on the learners themselves. That meant that parents still had to shoulder some of the challenges against the Free Primary Education policy. These strategies included; levying pupils PTA project funds while some parents paid in kind as a contribution to schools' infrastructure development and other needs, repaired desks, emphasized on remedial work/ homework policy, educated parents on the importance of education, emphasized on Continuous Profession Development (C,PDs), introduced sessions in schools, requested for more teachers from government, used Home Economics (HE) and production unit funds, combined classes or rather multi-grade system, involved cooperating partners for funding, requested for desks from government, built temporal accommodation for teachers, safe guarded the few books available and solicited for student teachers. These details are shown in Table 5.

Table 5: Frequency and percentage distribution of head teachers' responses on the strategies used to overcome some challenges of free education

\begin{tabular}{lcc}
\hline Strategy Used & $f$ & $\mathbf{\%}$ \\
\hline Levying all learners project fund & 21 & 87.5 \\
Repair broken school furniture & 18 & 75 \\
Emphasize homework and remedial work & 17 & 70.8 \\
Having meetings with parents & 17 & 70.8 \\
Emphasize teacher CPDs & 17 & 70.8 \\
Introduce teaching in sessions & 17 & 70.8 \\
Request for more teacher deployment & 16 & 66.6 \\
Fundraise using other means & 16 & 66.6 \\
Employ multi-grade teaching & 15 & 62.5 \\
Request cooperating partners for funding & 15 & 62.5 \\
Request for more school furniture & 14 & 58.3 \\
Build temporary accommodation for teachers & 14 & 58.3 \\
\hline
\end{tabular}

The study findings indicated that the school population growth due to free education had had pressure on the education facilities and resources. The resources included: financial, material and human. The Pupil Teacher Ratio, Pupil Book Ratio and Desk Pupil Ratio had increased abnormally. This had led to ineffective teaching and learning activities in schools and had created a conflict between access to education and quality of education supply in primary schools of Kafue District. In other words, it had created an imbalance between education demand and supply thereby compromising the quality of education offered.

Findings also revealed that the school requisites supplied did not correspond with the enrolment levels in schools. Teacher Pupil Ratios were very high, access and quality were thus compromised. The desk- pupil ratios were also so high that learners did not sit comfortably in classes and were discouraged leading to rampant absenteeism. In most 
schools, the Desk Pupil Ratio was 1:10; most of the pupils sat on the floor and on bricks. The Pupil Book Ratios were also very high, such that in many schools the ratio was 1:15. This is not very good for effective implementation of the curriculum because other studies such as those done by Moobola and Mulenga (2020); Musilekwa and Mulenga (2019) revealed that most of the books, especially social studies, that were distributed in schools for the revised curriculum were of very poor quality in terms of the accuracy of content. That made the work of teacher's very difficult leading to ineffectiveness in their execution of duties. In addition, teachers were over worked, they could not attend to individual pupils' needs, they could not use a variety of methods, and it was not easy to have effective remedial work. One wonders if teachers were even consulted on the model or ways of how MoGE implemented the policy of Free Primary Education given the number of challenges that came with it. However given the evidence from other studies such as those conducted by Mulenga and Mwanza (2019) and Mwanza and Mulenga (2018:81) it would be correct to agree with the duo that 'it seems teachers' thoughts are only allowed to be expressed in their classrooms' just as we discovered when this study was conducted. Teachers are rarely consulted on such significant curriculum development and implementation issues such as this policy. This compromised the quality of education delivery; hence, access and quality could not match.

The findings of the study were consistent with those reported by Kaulule (2006) on Zambian Education. The Ministry of General Education was supportive of Free Primary Education which resulted in massive increase in enrolment and led to overcrowding. Furthermore, the findings were also similar in some way to UNESCO (2006) who found that due to the introduction of free education, schools in Malawi had become overcrowded, poorly staffed, while teaching learning materials and other facilities were inadequate and sometimes not available. Saroso (2005) further stated that the effects of class size had some bearing on children's achievement. The findings on higher enrolments in Kafue were also consistent with those cited by (Duncan, Macmillan and Simutanyi, 2003) as having been available in Malawi, Kenya and Uganda in the process of implementing FBE/FPE in those countries. In addition, the findings were also in conformity with those by Plank (2007) who reported that after school fees were abolished in Malawi, the ratio of pupils to classrooms increased to 70:1, the ratio of pupils to teachers increased to $80: 1$, and the ratio of pupils to text books increased to $24: 1$. The same author also reported that the abolition of school fees in other countries including Uganda, Cameroon and Mozambique resulted in rapid increase in the pupil teacher ratios.

The study further revealed that there was a challenge of irregular and inadequate provision of free exercise books and other FPE materials. The findings revealed that $76.5 \%$ of the respondents indicated that the free exercise books and other materials were provided but were not adequate. It was also revealed that even though school was free, the Government was unable to provide all the school requisites. For example, in some schools, the government was only able to provide a maximum of four (4) text books per pupil. The rest of the books and other requirements were to be provided by the parents, 
but most of the parents were unable due to economic reasons. The study revealed that inadequate funding, poor accommodation, and delay in funding were ranked among the most serious conflicts that inhibited the implementation of the FPE policy in primary schools. To make matters worse the Ministry of General Education funding in Zambia has been very poor since 2014 with the funding to the ministry going down each subsequent year as explained by Mulenga and Kabombwe (2019b). All the teachers and administrators revealed that funding for the FPE was inadequate. In other words, the increase in access was in conflict with the supply of teaching and learning materials which led to severe strain on the budget because the government could not fully fund the policy as a result, poor quality education provision is what was noted.

The findings further revealed that as a result of the introduction of FPE, there was increased absenteeism among pupils. These have serious implications on the performance of a learner at every level of education. This circumstance brought about indiscipline in schools. When it came to academic work, they were given the same work and at times the results were made public, this discouraged some of them who even dropped out of school. These findings were in conformity with those identified by UNESCO (2006) in Kenya. This is why absenteeism and low literacy levels were ranked among the major challenges in the implementation of the FPE policy. From the mentioned challenges above, it could be concluded that the FPE policy had led to a compromise in quality of education provision in primary schools of Kafue district. Mulenga (2018) cautioned educationists on their assumed definition of a curriculum because this may lead to a mistaken understanding of quality education since our definitions of phenomenon has a great influence on the practice. The findings of this study seem to suggest that in Zambia they seem to be a misleading understanding of quality education provision and education enrollments among political and education leaders. The fact they there are many learners in school does not definitely mean that they is education being provided to such learners. This study has revealed just that.

\section{Conclusion and Recommendations}

From the study, it could be concluded that the higher enrolments created a conflict between access and delivery of quality education. There were challenges of government providing more teachers, more classrooms, more textbooks, more desks and other educational materials to meet the increased enrolment. When educational materials were provided, they were irregular and inadequate. The implementation of the FPE policy was characterized by inadequate and erratic funding from the government. The schools' environments were unconducive for teaching and learning purposes as most of the schools had over stretched facilities like classrooms which were congested with pupils squeezing on few available desks. Teachers handled more and congested classes to the extent that most learners were not taken care of. If this was the situation it would also be interesting to find out how the Ministry of General Education is actually implementing other policies such as the compulsory teaching of computer studies with such critical 
shortage of teaching and resources, funding and overcrowded classrooms. From what Masumba and Mulenga (2019) had noted in their study this could be another highly compromised area of curriculum implementation. Furthermore, there was inadequate teaching staff which forced schools to combine classes. In other words, there were fewer text books and other materials compared to the number of pupils. It is a well-known fact that several scholars including Mulenga and Chileshe (2020) have put emphasis that teaching and learning resources are key to effective implementation of any curriculum. Thus, the implementation of Free Primary Education Policy was supposed to be seen in the light of what exited in Zambia in terms of the availability of such resources since the policy meant that enrollments would increase. All the above-mentioned challenges impacted negatively on the quality of education delivery in primary schools of Kafue District. The Free Primary Education policy implementation in primary schools of Kafue district had compromised quality of education. Researchers are making recommendations that the government should adequately fund the policy or abolish it all together because free education should go with quality. Otherwise what is happening in schools in Kafue cannot be regarded as free education but free enrollment. Secondly, parents should pay a small fee which should help schools to use for daily school requirements.

\section{About the Authors}

Christine Mwanza is a lecturer at the University of Zambia in the school of education. Mrs. Mwanza holds a Bachelor of Arts with Education and a Master of Education in Curriculum Studies from the University of Zambia and a Master of Education in International Education and Development. Her areas of research interest include curriculum development, pedagogy and education, teacher education, professional development, education and development.

Darious Silukuni is a secondary school teacher in Kafue district in Zambia. He has taught in Secondary school for over five years. He holds a Master of Education degree in Educational Management from the University of Zambia and a Bachelor of Arts with Education degree also from the same institution. His research interests are in Educational Administration and Leadership, Curriculum Implementation, Educational Planning and Economics of Education.

\section{References}

Beiter, D. K. (2006). The Protection of the Right to Education by International Law. London: Martinus Nijhoff Publishers.

Duncan, A., Macmillan, H. and Simutanyi, N. (2003). Zambia, Drivers of Pro-Poor Change: An Overview. Oxford: Oxford Policy Management.

Deininger, K. (2003). Does Cost of Schooling Affect Enrolment by the Poor? Universal Primary Education in Uganda. Economics of Education Review, 22, 291-305 
Kattan, R. B. (2006). Implementation of Free Basic Education Policy. Washington DC: World Bank.

Kaulule, R. S. (2006). Effects of Free Education Policy in Selected Basic Schools of Ndola and Masaiti Districts of Copperbelt Province, Zambia. Med Dissertation. Lusaka: The University of Zambia.

Kelly, M. J. (1999). The Origin and Development of Education in Zambia: From Pre-Colonia Times to 1996. Lusaka: Image Publishers Limited.

Kelly, M. J. (1991). Education in a Declining Economy. Washington D.C. World Bank.

Knight, E. and Sabot, W. (1990). Education, Productivity and Equity. Paris: Oxford University Press.

Maslow, A. H. (1970). Motivation and personality. New York: Harper and Row.

Maslow, A. H. (1968). Toward a Psychology of Being. New York: D. Van Nostran Company. Masumba, C. K. and Mulenga, I. M. (2019). Teachers' pedagogical content knowledge for teaching Computer Studies in rural Zambian secondary schools of North-western Province. Zambia Journal of Library E Information Science (ZAJLIS). 3 (1 \& 2). 90-106.

Ministry of Education (2002). Educational Statistical Bulletin. Lusaka: Ministry of Education.

Ministry of Education (1996). Educating Our Future: National Policy on Education. Lusaka: Zambia Educational Publishing House.

Moobola, L. and Mulenga, I. M. (2020). Social Studies Curriculum at The Crossroads: Implementation of the Secondary School Social Studies Curriculum in Chingola district of Zambia. European Journal of Education Studies. 7(3), 13-34. http://dx.doi.org/10.5281/zenodo.3750518.

Mukudi, E. (2004). Education for All: A Framework for Addressing the Persisting Illusion for the Kenyan Context. International Journal of Education Development. 24(3), 231240. http://doi:10.1016/j.ijedu.dev.2003.10.009.

Mulenga, I. M. (2018). Conceptualization and Definition of a Curriculum. Journal of Lexicography and Terminology. 2 (2), 1-23.

Mulenga, I. M. and Chileshe, E. K. (2020). Appropriateness and Adequacy of Teaching and Learning Resources and Students' Industrial Attachment in Public Colleges of Technical and Vocational Education in Zambia. East African Journal of Education and Social Sciences. 1(2), 30-42. https://doi.org/10.46606/eajess2020v01i02.0019.

Mulenga, I. M. and Kabombwe, M. Y. (2019a). Understanding a Competency-Based Curriculum and Education: The Zambian Perspective. Journal of Lexicography and Terminology, 3(1). 106-134.

Mulenga, I. M. and Kabombwe, M. Y. (2019b). A Competency-Based Curriculum for Zambian Primary and Secondary Schools: Learning from Theory and some Countries around the World. International Journal of Education and Research, 7(2), 117-130. http://www.ijern.com/journal/2019/February-2019/10.pdf.

Mulenga, I. M. and Lubasi, I. M. (2019). Teachers Present in School but Absent in Class: 
Utilization and 'Silent Erosion' of Learning Time in the Implementation of the Curriculum in Mongu District of Zambia. European Journal of Education Studies, 6(2), 61-79. http://dx.doi.org/10.5281/zenodo.2678061.

Mulenga, I. M. \& Mwanza, C. (2019). Teacher's Voices Crying in the School Wilderness: Involvement of Secondary School Teachers in Curriculum Development in Zambia. Journal of Curriculum and Teaching. 8(1). 32-39. https://doi.org/10.5430/jct.v8n1p32.

Musilekwa, S. and Mulenga, I. M. (2019). Development of Social Studies Learners' Textbooks for Secondary Schools in Zambia. Journal of Education and Practice, 10(6), 99-108.

Mwanza, C. and Mulenga, I. M. (2018). Voices Confined to Classrooms: The Marginalised Status of Teachers in Curriculum Development in Lusaka, Zambia. Multidisciplinary Journal of Language and Social Sciences Education, 1(2), 63-83.

Nielsen, H. D. (2009). Moving Toward Free Primary Education: Policy Issues and Implementation Challenges- $A$ state of the Art Review: UNICEF Policy and Practice.

Oxfam (2001). Education Charges: A tax on Human Development. Oxfam Briefing Paper Number 3.

Plank, D. (2007). School fees and education for all: Is abolition the answer? EQUIP2 project working paper. Academy for Educational Development. Washington DC: USAID.

Saroso, O. (23rd March 2005). The Poor Still Waiting for Government Assistance. The Jakarta Post, pp.16-20.

Siaciwena, R. and Lubinda, F. (2008). The Role of Open and Distance Learning in the Implementation of the Right to Education in Zambia. Volume 9(1).

Sikwibele, A. (2003). Editorial Assessment of Educational Policy: Free Education Policy in Zambia. DPMN Bulletin, Volume x (1).

Tembo, K and Ndhlovu, G. (2005) Government Strives to Increase access to Education. News from Africa: Kenya.

UNESCO (2003). EFA Global Monitoring Report 2005: Education for All: The Quality Imperative. Paris: UNESCO.

UNESCO (2006). Assessment of Free Primary Education-Fact Book in line with Education for All. Nairobi: UNESCO.

UNICEF and World Bank (2009). Africa Human Development Series, Development Practice in Education. Paris: World Bank Publications.

Verspoor, M. A. (2008). At the Crossroads Choice for Secondary Education in Sub-Saharan Africa. London: World Bank Publications. 
Author(s) will retain the copyright of their published articles agreeing that a Creative Commons Attribution 4.0 International License (CC BY 4.0) terms will be applied to their work. Under the terms of this license, no permission is required from the author(s) or publisher for members of the community to copy, distribute, transmit or adapt the article content, providing a proper, prominent and unambiguous attribution to the authors in a manner that makes clear that the materials are being reused under permission of a Creative Commons License. Views, opinions and conclusions expressed in this research article are views, opinions and conclusions of the author(s). Open Access Publishing Group and European Journal of Education Studies shall not be responsible or answerable for any loss, damage or liability caused in relation to/arising out of conflicts of interest, copyright violations and inappropriate or inaccurate use of any kind content related or integrated into the research work. All the published works are meeting the Open Access Publishing requirements and can be freely accessed, shared, modified, distributed and used in educational, commercial and non-commercial purposes under a Creative Commons Attribution 4.0 International License (CC BY 4.0). 